\title{
水流による砂れきの移動機構に関する基礎的研究 \\ STUDY ON MECHANISM OF MOTION OF INDIVIDUAL SEDIMENT PARTICLES
}

\author{
中 川 博 次* - 辻 本 哲 郎** \\ By Hiroji NAKAGAWA and Tetsuro TSUJIMOTO
}

\section{1. 序論}

河床波の発生・発達, 河床の洗掘・堆積など移動床現 象に関する研究は従来から数多く行われているが, 現象 自体が多様であり，また支配要素が膨大でしかもそれら 相互の関係が複雑であることから，これらの現象を統一 的かつ合理的に説明しうる十分な成果が得られていると はいい難いようである。

移動床現象では, 流れ, 流砂および河床形状が複雑に 関係しあっており，特に実際の河川では流れの非一様性 に基づいて流砂の非平衡が生じ, 河床形状が複雑に変化 し, 再び流れの変化を産み出すという閉じた系を形成し ているといえる。こうした移動床現象に対し, 平衡平担 河床について得られた流砂量公式を流砂の運動方程式に 代用した現象記述がよく試みられているが，こうした解 析方法はすでに指摘されているようにある断面の流砂量 が単にその位置での底面せん断応力だけに対応していな いことから考えても, 流砂の非平衡の生じている状態で は合理性を欠く恐れがある。このことは, Einstein ${ }^{1)} に$ よって始められた 砂れきの河床からの離脱率 (pickup rate), いったん河床から動き出して停止するまでの距離 (step length) によって流砂を表現するモデルを考える とよくわかる。すなわち，打もに水理量に対応する pickup rate は各断面につき固有のものであるが，流砂 量となると step length によって明らかに上流の影響 を受ける。もともと Einstein のモデルでは, 図一1に 示すように砂れきの移動を Lagrange 的に追跡した形 であるが, この形では水理条件, 床面条件の場所的変化 を十分取り入れることが困難であるから，ここではこれ らの量を Euler 的に扱って河床変動などを容易に記述 しうることを期待する。

* 正会員 工博 京都大学教授 工学部土木工学教室

** 学生会員 工修 京都大学大学院博士課程
本研究は,さまざ まな移動床現象は個 々の砂粒の移動特性 に基ついて合理的に しかも統一的に表現 されるべきである との立場から, 砂れ きの pickup rate,

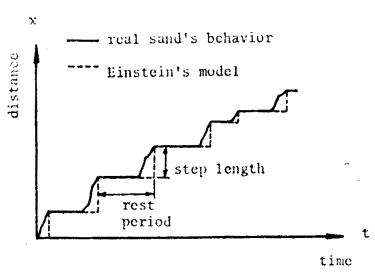

図一1 砂移動のモデル step length を個々の砂粒の運動特性の代表量として選 び，その力学機構を明らかにし，定量的に把握しようと するものである。Einstein ${ }^{2,3)}$, Paintal $^{4)}$ らはむしろ直 観的にこれらの量を水理量と結びつけているが，たとえ ば pickup rate の基礎となる砂れきの移動確率は 図一 2 に示すように互いに大きく相違し, pickup rate 推定 のとき瞹味さが残る。すなわち pickup rate, step length をひっくるめて初めて流砂量といった塞際量を表わ すだけで, 各量のままでは実験值との対応はついておら ず，本研究では砂れきの運動機構に基づいてこれらの量 の推定を試み，実験的に検討している。

このようにして, pickup rate および step length が

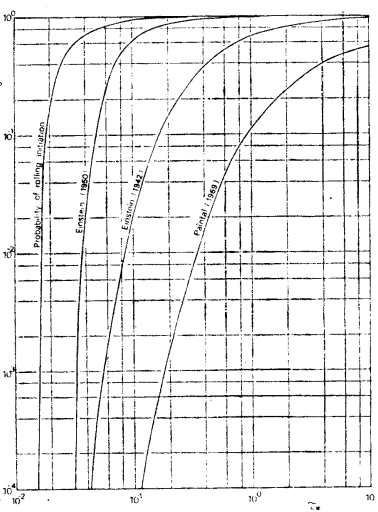

図一2 砂の移動確率の評価 の比較
推定されれば，砂れき の拡散を確率過程と して扱った stochastic model ${ }^{5), 6)}$ の確率定数 を合理的に与え得たこ とになり，流砂の連続 式と組み合わせること で河床変形過程の記述 も可能である。 なお, 本研究では, 河床砂れきが運動状態 にはいるまでを離脱過 程, いったん運動を開 始した砂れきが再び河 
床に落ち着き停止するまでを流送過程とよび，それぞれ

2.および 3.に拈いて扱った。

\section{2. 砂れきの河床からの離脱過程}

\section{（1）砂れきの初期移動}

砂れきの河床からの初期移動形式は, 転動, 滑動およ び転動と滑動と多様であるが，いずれにせよ，従来の研 究では静的な力のつり合いによって移動限界を求めると いう立場がとられてきた。しかし実験による観察では， 移動開始前に小刻みな摇動が見られるなど, Chen ら゙) が指摘するように移動開始は明確な限界値で規定され ず, 初期段階と最終段階の間に遷移領域が存在すること を考慮すると, むしろ離脱過程として運動方程式で表現 寸るのが好ましいと考えられる。実験によると, 流体力 があまり大きくないときには, 砂粒は下流側の隣接砂粒 に沿って転動離脱することが観察され，流体力が大きく なると, 転動の途中で滑動に移行する。本研究では, こ の転動離脱に着目して, 転動過程を運動方程式によって 表現することにする。

\section{（2）砂粒の転動離脱モデル}

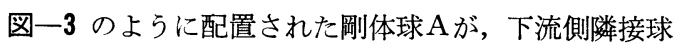
$\mathrm{B}$ に沿って転動して離脱するものとする。球 $\mathrm{A}$ には水中

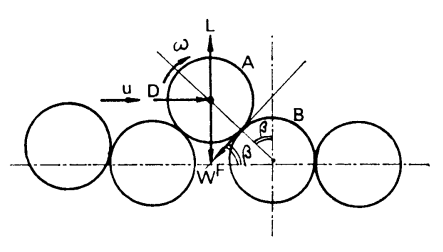

図一3 記 号 図 重量 $W$, 抗力 $D$, 揚力 $L$ が作用し， その作用線はすべ て重心を通るもの とする。また, 球 $\mathrm{A}$, 球 B の接線と 平均河床面とのな

す角を $\theta$ とし, $\mathrm{AB}$ 間の摩擦力を $F$ とする。河床勾配 を 0 とすると, 球Aの重心まわりの回転に対する運動方 程式は次式で与えられる。

$$
M d \ddot{\theta}=(L-W) \sin \theta+D \cos \theta-F
$$

ここに, $d:$ 砂粒径, $M$ : 球の仮想質量である。

また, 球 $\mathrm{A} の$ 重心まわりの回転に関するモーメント式 は,

$$
M k \dot{\omega}=F d / 2
$$

であり, $k$ は球 $\mathrm{A}$ の重心に関する回転半径, $\omega$ は転動 の回転角速度である。完全転動を仮定すると，

$$
\dot{\theta}=\omega / 2
$$

である。式（2）および（3）より，

$$
F=4 M k^{2} \ddot{\theta} / d
$$

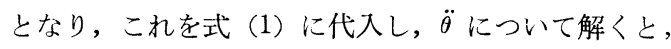

$$
\ddot{\theta}=\{(L-W) \sin \theta+D \cos \theta\} /\left\{M d\left(1+\frac{4 k^{2}}{d^{2}}\right)\right\}
$$

となる。ところで,

$$
\left.\begin{array}{l}
M=\rho\left(\sigma / \rho+C_{M}\right) A_{3} d^{3} \\
W=(\sigma-\rho) A_{3} g d^{3}
\end{array}\right\}
$$

であり，ここに， $\sigma, \rho:$ それぞれ砂粒および流体の密度， $A_{3}$ : 体積に関する形状係数, $C_{M}:$ 付加質量係数であ る。また，

$$
\left.\begin{array}{l}
D=\frac{1}{2} C_{D} \rho u^{2} A_{2} d^{2} \\
L=\frac{1}{2} C_{L} \rho u^{2} A_{2} d^{2}
\end{array}\right\}
$$

と表わされる。ここに, $C_{D}$ : 抗力係数, $C_{L}$ : 揚力係数, $A_{2}$ : 面積に関する形状係数, $u$ : 球 $\mathrm{A}$ 近傍の局所代表流 速である。なお，

$$
\begin{aligned}
& L / D=k_{1} \cdots \\
& u / u_{*}=A_{*}
\end{aligned}
$$

と打き, 初期角加速度 $\ddot{\theta}_{0}$ を求めると, $\theta=\beta$ ( $\beta$ 注河床 に停止しているときの下流側隣接砂粒との接線と, 平均 河床面とのなす角）とおいて，

$$
\ddot{\theta}_{0} d / g=B_{*} C_{*}\left(k_{1} \sin \beta+\cos \beta\right)\left(\tau_{*}-\tau_{* c}\right) \cdots(9)
$$

となる。ただし， $\tau_{*}$ は無次元底面せん断応力であり，

$$
\tau_{*}=u_{*}^{2} /\{(\sigma / \rho-1) g d\}
$$

である。また，

$$
\begin{aligned}
& B_{*}=(\sigma / \rho-1) /\left\{\left(\sigma / \rho+C_{M}\right)\left(1+\frac{4 k^{2}}{d^{2}}\right)\right\} \\
& C_{*}=\frac{1}{2} \frac{A_{2}}{A_{3}} A_{*}^{2} C_{D}
\end{aligned}
$$

であり, 明らかに $B_{*}$ は相対密度 $\sigma / \rho$ の効果および形 状効果を示し, $C_{*}$ は形状効果と砂粒レイノルズ数 $\left(R_{e *}\right.$ $=u_{*} d / \nu, \nu:$ 流体の動粘性係数) の関数である。

なお， $\tau_{* c}$ は転動限界に対応する無次元せん断応力 で, 球 $\mathrm{A}, \mathrm{B}$ の接点まわりのモーメントのつり合いか ら,

$$
\tau_{* c}=2 \frac{A_{3}}{A_{2}} \sin \beta /\left\{A_{*}^{2} C_{D}\left(k_{1} \sin \beta+\cos \beta\right)\right\}
$$

である。なお上式は砂粒相互間の拘束および砂面の凹凸 による干渉作用を無視しているので，これらの効果を表 わす倸数 $\epsilon$ を導入して $\epsilon \tau_{* c}$ を新しく $\tau_{* c}$ と置き換え る。ここに $\epsilon$ はいわゆる遮蔽係数である。

\section{（3）砂れきの河床からの pickup rate}

砂粒は式（9）で表わされる初期角加速度で河床から 離脱するが，流体力は乱れによって変動している。い ま, 砂れきの初期移動に関与寸る底面せん断応力の変動 周期を $\hat{t}_{0}$, このうち $\tau_{*} \geqq \tau_{* c}$ である応力が作用する平 
均時間を $\left\langle t_{0}\right\rangle$ とし，〈to $\rangle$ 時間だけ $\tau_{* c}$ をこえる分の平 均の底面せん断応力が作用するものと仮定する。

$\tau_{*} \geqq \tau_{* c}$ となる確率を $p_{0}$ とすると,

$$
\left\langle t_{0}\right\rangle=p_{0} \hat{t}_{0}
$$

の関係が成立する。ここで $\hat{t}_{0}$ は砂粒の 流体力に対する 応答性に関する量であるから，たとえば砂粒の固有振動 数を考慮し, さらに水中重量の効果をあわせ考えると，

$$
\hat{t}_{0}=F_{*} \sqrt{(\sigma / \rho-1) d / g}
$$

と仮定することができる。ここに $F_{*}$ は実験定数とした が， $F_{*}$ は砂れきの水中での追従性に関連する 重要な量 で，今後基礎的な実験を通して詳細な検討が望まれる。 なおこの式の妥当性は後述の実験結果からも確認され る。

このとき,一つの砂粒が離脱してしまうのに要する時 間 $\langle T\rangle$ は,

$$
\langle T\rangle=\beta /\left(k_{2} E[\ddot{\theta}] p_{0} \hat{t}_{0}\right)
$$

となる。ここに $k_{2} E[\ddot{\theta}] p_{0} \hat{t}_{0}$ は砂粒の離脱の際の平均角 速度で, $k_{2}$ は離脱時の $\theta$ の変化に伴う角加速度の変化 のしかたなどによる補正係数である。また $E[\ddot{\theta}]$ はせ し断応力の変動に対する期待值を表わす。

$p_{0} \hat{t}_{0}$ 時間に離脱する 砂粒個数は $p_{0} \hat{t}_{0} /\langle T\rangle$ で与えら れ, したがって単位時間当りの離脱砂粒数を全体の時間 にわたって考えると, 結局 pickup rate $p_{s}$ は

$$
p_{s}=\left(p_{0} \hat{t}_{0} /\langle T\rangle\right) \cdot\left(1 / \hat{t}_{0}\right)
$$

となる。

$$
\begin{aligned}
& \text { 式 (9), (13), (14),(15) および (16) より, } \\
& \begin{aligned}
p_{s} \sqrt{d /(\sigma / \rho-1) g} \\
=F_{*} k_{2} B_{*} C_{*}\left\{\left(k_{1} \sin \beta+\cos \beta\right) / \beta\right\} \\
\quad \cdot p_{0}{ }^{2}\left\{E\left[\tau_{*} \mid \tau^{*} \geqq \tau_{* c}\right]-\tau_{* c}\right\} \ldots \ldots \ldots . . . . .
\end{aligned}
\end{aligned}
$$

の関係が得られる。

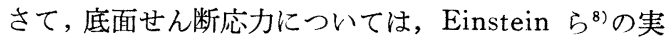
験結果に基づいて正規分布するものと仮定し, 無次元せ ん断応力 $\tau_{*}$ の確率密度関数を $f\left(\tau_{*}\right)$ とすると,

$$
f\left(\tau_{*}\right) d \tau_{*}=\frac{1}{\sqrt{2 \pi} \sigma_{*}} \exp \left[-\frac{\left(\tau_{*}-\tau_{* c}\right)^{2}}{2 \sigma_{*}^{2}}\right] d \tau_{*}
$$

である。ここに $\tau_{* 0}, \sigma_{*}{ }^{2}$ はそれぞれ 無次元せん断応力 $\tau_{*}$ の平均值および分散である。なお,

$$
r=\left(\tau_{*}-\tau_{*_{0}}\right) / \sigma_{*}=\left(\tau_{*} / \tau_{*_{0}}-1\right) / \eta_{0}
$$

とおくと, $\eta_{0}$ は変動係数 $\left(\eta_{0}=\sigma_{*} / \tau_{* 0}\right)$ で, 式 (18) は,

$$
\phi(r) d r=(1 / \sqrt{2 \pi}) \exp \left(-r^{2} / 2\right) d r
$$

となる。このとき，

$$
p_{0}=\int_{r_{c}}^{\infty} \phi(r) d r / \int_{-1 / \eta_{0}}^{\infty} \phi(r) d r
$$

で与えられる。ここに，

$$
r_{c}=\left(\tau_{*_{c}} / \tau_{*_{0}}-1\right) / \eta_{0}
$$

である。また，

$$
\begin{aligned}
& E\left[\tau_{*} \mid \tau_{*} \geqq \tau_{* c}\right]=\tau_{* 0}\left(1+\eta_{0} r_{s}\right) \\
& r_{s}=\int_{r_{c}}^{\infty} r \phi(r) d r / \int_{r_{c}}^{\infty} \phi(r) d r \fallingdotseq \phi\left(r_{c}\right) / p_{0}
\end{aligned}
$$

である。したがって, 式（17）は次のようになる。

$$
\begin{aligned}
& p_{s} \sqrt{d /(\sigma / \rho-1) g}=F_{* k_{2} B_{*} C_{*}} \\
& \quad \cdot\left\{\left(k_{1} \sin \beta+\cos \beta\right) / \beta\right\} f_{p}\left(\tau_{*}\right) \\
& f_{p}\left(\tau_{* 0}\right)=p_{0}{ }^{2} \tau_{* 0}\left\{1+\eta_{0} \frac{\phi\left(r_{c}\right)}{p_{0}}-\frac{\tau_{* c}}{\tau_{* 0}}\right\}
\end{aligned}
$$

である。

いま, 球を対象とすると, $A_{3}=\pi / 6, k^{2}=d^{2} / 10$ であ り, また簡単のため $A_{2}=\pi / 4, C_{M}=0.5$ と仮定すると, $B_{*}$ は相対密度 $\sigma / \rho$ 関数として 図一4のように示され る。

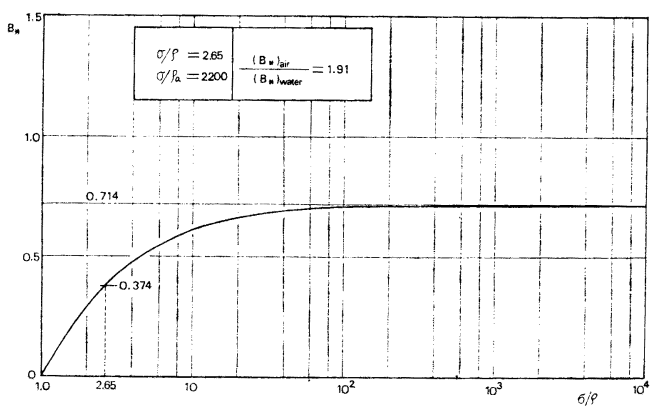

図一4 $B_{*}$ の $\sigma / \rho$ に対する変化

また, Chepil ${ }^{9)} ら$ の実験結果による と, 河床砂れきに作 用する揚力と抗力の 大きさはほぼ同程度 と考えられるから， $k_{1}=1.0$ とおき，基 準面の高さを粗度を 構成している砂粒の 頂部から $0.25 d$ だ け下にとって対数流 速分布を用いること にする。なお，Einstein \& El-Samni ${ }^{8)}$, Chepil $^{9)}$ を始め多く の実験結果 ${ }^{10) ~ 13)}$ か ら壁面近傍の乱れに よる圧力変動係数は レイノルズ数に対し

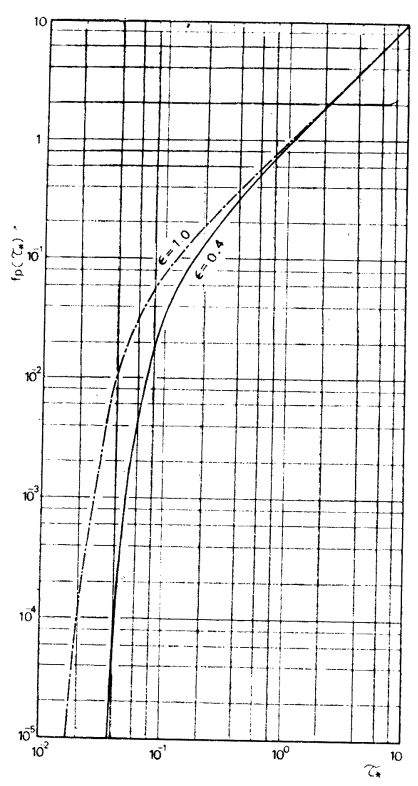

図一5 $\boldsymbol{f}_{p}\left(\boldsymbol{\tau}_{*}\right)$ ほぼ一定で約 0.5 であり，これを $\eta_{0}$ として用い， $\beta=$ $\pi / 4$ として式 (26) を， $\epsilon=1.0$ および $\epsilon=0.4$ の場合に ついて計算した結果を 図一5 に示した。 


\section{（4）砂れきの初期移動に関する実験的検討}

砂れきの pickup rate はある領域から動き出す砂れ き個数の測定, あるいはトレーサーの原点残留確率（原 位置にとどまっている確率) の時間的変化の測定によっ て知ることができる。

いま時刻 0 におけるトレーサー数を $N$ とすると，時 刻 $k \Delta t$ での 原点残留個数は $N\left(1-p_{s} \Delta t\right)^{k}$ となり, 原 点残留確率 $P_{0}$ の 時間的変化 は, $k \rightarrow \infty, \Delta t \rightarrow 0$ とす ると，

$$
P_{0}(t)=\exp \left(-p_{s} t\right)
$$

となり, いわゆる stochastic model で飛び出し時間間 隔を指数分布と仮定したときの結果と一致する。stochastic model の立場でのトレーサーを用いた原点残留確 率の時間的変化が篠原・椿 ${ }^{14)}$, 高橋 ${ }^{15)}$, 矢野・土屋・道

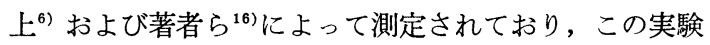
值をもとに実験定数 $F_{*} k_{2}$ を $3.2 \times 10^{-2}$ と決めた。図 一6にはこれらの実験值および $\sigma / \rho=2.65,1.24$ に対す る $B_{*}$ を用いた計算曲線が描かれている。なお抗力係数 として球の静水沈降時の值を代用し $C_{D}=0.4$, また $A_{*}$ $=6.55, \epsilon=0.4$ とした。この図によると, 実験值と理論 曲線は良い対応を示し, 式 (25) によって砂れきの pickup rate が十分推定できることがわかる。

次に, 遮蔽係数 $\epsilon$ の值の妥当性の検討のため, ガラス ビーズ $(d=0.5,0.3 \mathrm{~cm} ; \sigma / \rho=2.38)$ を用いて, 移動床 での初期移動の実験と固定床上の非拘束砂粒の初期移動

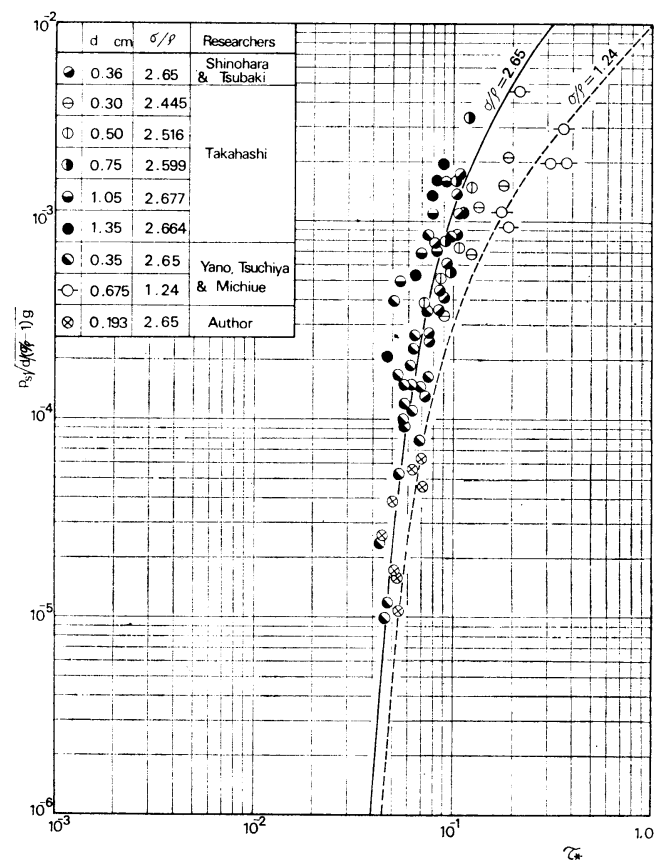

図一6 砂れきの pickup rate

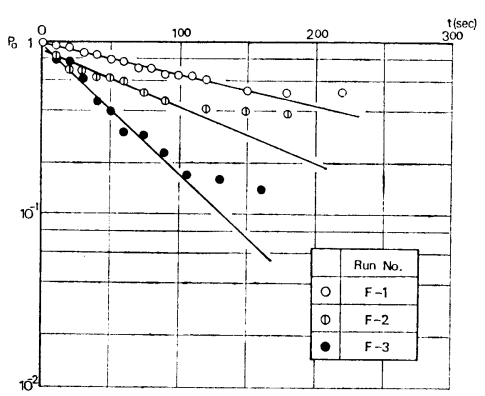

図一7固定床でのトレーサーの原点残留確率 の時間的変化の例

の実験とを行って比較した。

実験は, 長さ $9 \mathrm{~m}$, 幅 $33 \mathrm{~cm}$, 深さ $33 \mathrm{~cm}$ のアクリ ル製側壁をする鋼製勾配可変水路で行った。

固定床実験では所定のガラスビーズを 1 層, 密に敷き つめニス付けして作成された粗面上におかれた着色非拘 束ビーズをトレーサーとし，写真撮影によって原点残留 確率を測定した。なお，この場合の原点とは原位置とい う意味でトレーサーごとに位置は異なる。また 1 つの実 験に用いたトレーサーは 60 150 個である。図一7 は固 定床でのトレーサーの原点残留確率の時間的変化の例で あり，これより式 (27) を用いて Ps を求めた。図一7 によると時間がある程度経過した後は, 式 (28) よりは ずれてくるがこれは, 時間が経過するにつれて動きやす い状態のものがなくなりしかも補充されないことから $p_{s}$ が時間的に変化することによる。

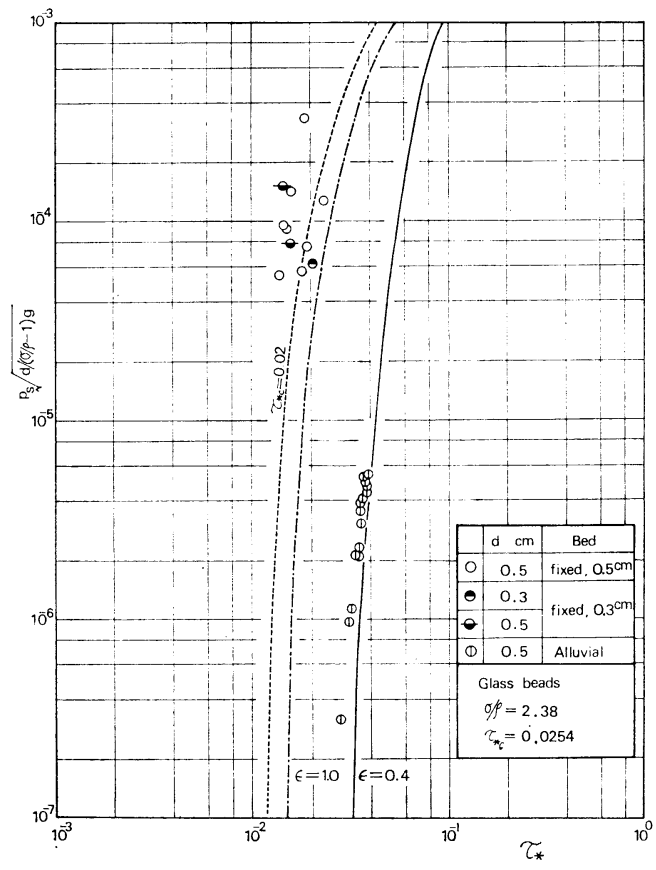

図-8 遮蔽係数の検討 
一方, 移動床実験は水路中央部の幅 $22 \mathrm{~cm}$, 長さ 7.5 $\mathrm{cm}$ の部分を移動床にし，ここからの移動開始個数を測 定した。

なお, 実験はほぼ等流状態で実施し, 摩擦速度は $\sqrt{g h i}$ ( $h:$ 水樑, $i:$ 路床勾配) で求め, 流速分布に対数則を 仮定して得られた $u_{*}$ でチェックした。

こうして得られた実験結果を 図一8 に示した。図一8 によると, 移動床の実験值はほぼ一定の傾向を示すが, 固定床の実験值は散乱が大きくこれはすでに述べたよう な $p_{s}$ の時間的変化, トレーサーの配置, 通水後等流状 態が得られるまでのトレーサーの保存など実験技術の困 難さによるものと考えられる。

なお，図中の曲線は， $\epsilon \tau_{* c}=0.0254$ とし， $\epsilon=0.4$ お よび 1.0 の場合について式 (25) を計算したものであ $\eta$, 実験定数 $F_{*} k_{2}$ は前と同じ值を用いている。なお, $\epsilon \tau_{* c}=0.0254$ は, ガラスビーズを並べた 斜面の勾配を 徐々に変化させてトレーサーの斜面落下の累積確率を測 定した結果 (図一9) から $\beta$ が $\pi / 10$ から $(3 / 10) \cdot \pi の$ 範囲で一様に分布するものとして式 (12) より決めたも のである。

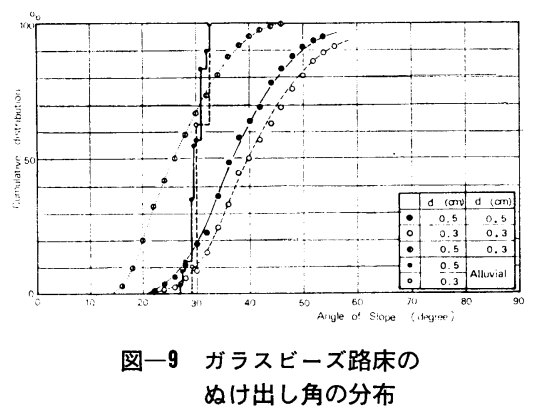

図一8を見れば，固定床実験で $p_{s}$ を測定することの 困難さによるデータの散乱が認められるが， $\epsilon$ の推定は ほぼ妥当といえる。

以上の考察から，(2)，(3) で展開した初期移動モデル では，多くの仮定を用いているもののここに示したよう に異なった実験材料に対してもよくその特性を示し，こ のモデルで初期移動現象を十分記述し得るものと考えら れる。

\section{3. 砂れきの流送過程}

砂れきがいったん移動を開始し 再び河床に 停止する までの流送過程を代表する量は step lengthである。 pickup rate と結びつけて流砂量式を導くために Einstein $^{2), 3)}$, Paintal ${ }^{4)}$, Christensen \& $\mathrm{Chiu}^{17)}$ らによっ て step length の推定式が与えられているが, 従来の 実験値との対応も満足すべきものではない。
ここでは, 砂れきの step length が特に床面特性の 大きな影響を受けることから，ランダムな突起を有する 床面での衝突を考えることで step length の特性表示 を試みる。

\section{（1）固定床での流送機構}

実験観察によれば，砂れきは粗面の突起に妨げられて 停止することが多く，また動き出した直後の移動速度の 小さいものは停止しやすく，かなり速度が大きくなった ものは停止しにくいことがわかった。こうした事実か ら，いったん動き出した砂れきが停止するときには突起 との衝突が力学的に卓越した現象であると考えられ，こ れに基づいてモデル化を行った。

a）球の突起への衝突モデル

まず，転動中の砂れきが床面上の突起に衝突する場合 を考える。

図一10のように 角速度 $\omega_{1}$, 速度 $v_{1}$ の球が高さ $\Delta_{b}$ の突 起に衝突後, 角速度 $\omega_{2}$, 速度 $v_{2}$ になる ものとする。衝突の 前後に運動量保存則 を適用すると，

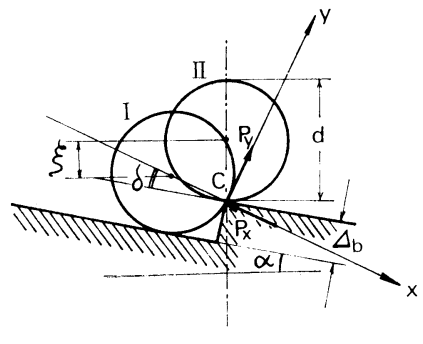

図-10 記 号 図

$$
\begin{gathered}
-\int_{0}^{t_{c}} P_{x}(\tau) d \tau=M\left(0-v_{1} \cos \delta\right) \\
\int_{0}^{t_{c}} P_{y}(\tau) d \tau=M\left(v_{2}-v_{1} \sin \delta\right)
\end{gathered}
$$

であり,また球の中心に対する回転の角運動量変化につ いて次式が得られる。

$$
-\frac{d}{2} \int_{0}^{t_{c}} P_{y}(\tau) d \tau=M k^{2}\left(\omega_{2}-\omega_{1}\right)
$$

ここに, $t_{c}$ は衝突時間であり, 他の量は 図一10 に準拠

する。なお, 球の運動を完全転動と仮定すると,

$$
v=\omega d / 2
$$

であり，また 図一10より明らかなように，

$$
\sin \delta=1-2\left(\Delta_{b} / d\right)
$$

であるから, 式 (29)〜 (32) から衝突前後の速度および 角速度の関係式,

$$
\frac{v_{2}}{v_{1}}=\frac{\omega_{2}}{\omega_{1}}=\frac{1+4\left(k^{2} / d^{2}\right)-2\left(\Delta_{b} / d\right)}{1+4\left(k^{2} / d^{2}\right)}
$$

が得られる。

次に, 図一10の I, II の状態に対してエネルギー保 存則を適用すると，

$$
-M g \hat{\xi}=(1 / 2) I^{\prime}\left(\omega_{3}{ }^{2}-\omega_{2}{ }^{2}\right)
$$

である。ここに, $\boldsymbol{\xi}$ は I, II における球の高さの変位, $\omega_{3}$ は II の状態での球の角速度である。また $I^{\prime}$ は 図一 10 の C 点まわりの転動に対する慣性モーメントである 
から, 平行軸の定理より，

$$
I^{\prime}=M\left\{k^{2}+\left(d^{2} / 4\right)\right\}
$$

と表わされる。

ところで, 球が突起を乗り越える条件は $\omega_{3} \geqq 0$ であ り，したがって $\omega_{1}$ の限界值 $\omega_{c}$ は式 (33)，(34）およ び（35）から次のようになる。

$$
\omega_{c}=\frac{\sqrt{2 g \hat{\xi}\left\{1+4\left(k^{2} / d^{2}\right)\right\}}}{1+4\left(k^{2} / d^{2}\right)-2\left(\Delta_{b} / d\right)} \cdot \frac{2}{d}
$$

なお, 図一10より,

$$
\begin{aligned}
\hat{\xi}= & \frac{d}{2}\left\{1-\sqrt{1-\left(1-\frac{2 \Delta_{b}}{d}\right)^{2}} \sin \alpha\right. \\
& \left.-\left(1-\frac{2 \Delta_{b}}{d}\right) \cos \alpha\right\} \ldots \ldots \ldots \ldots \ldots . . .
\end{aligned}
$$

である。

$\alpha=0$ とおき, $\omega_{c}$ を無次元表示すると,

$$
\omega_{c} \sqrt{\frac{d}{g}}=\frac{2 \sqrt{2 \Delta_{*}\left\{1+4\left(k^{2} / d^{2}\right)\right\}}}{1+4\left(k^{2} / d^{2}\right)-2 \Delta_{*}}
$$

となる。ただし，

$$
\Delta_{*}=\Delta_{b} / d
$$

である。

\section{b）転動距離と転動速度}

実際の流送過程には滑動, 転動, 跳躍あるいは反発現 象が混在していてそれらの機構が単独で一つの step を 形成しでいるわけではない。

ここでは現象記述のため, 卓越現象による表現という よりもむしろ包括的な表現として優れていると考えられ る転動形式を採用した。

転動過程に対する運動方程式は，揚力が無視されると 考えて,

$$
\begin{aligned}
& M \dot{u}_{g}=-F+(1 / 2) C_{D} \rho A_{2} d^{2}\left(\tilde{u}-u_{g}\right)^{2} \\
& M k^{2} \dot{\omega}=F d / 2 \ldots \ldots \ldots \ldots \ldots \ldots \ldots \ldots \ldots \ldots \ldots \ldots \ldots \ldots \ldots \ldots \ldots \ldots \ldots \ldots \ldots
\end{aligned}
$$

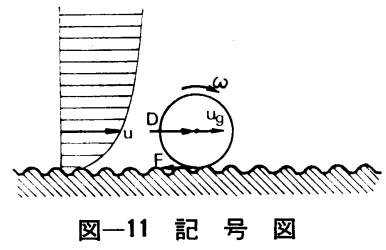

で表わされる（図一11 参照)。ここに, $u_{g}$ は 砂れきの移動速度， $\tilde{u}$ は転動砂れきの中心の 高さの局所流速であ る。をた，転動状態に 対し，上に述べたよう な包括的表現のために生ずる運動様式に関するパラメー ター $k_{3}$ を用いて, 次式が成立するものとする。

$$
\omega=k_{3} \cdot u_{g} d / 2
$$

式 (41) および (42) から,

$$
F=M \cdot\left(4 k^{2} / d^{2}\right) k_{3} \dot{u}_{g}
$$

が得られ,これを式 (40) に代入して $\dot{u}_{g}$ について解くと，

$$
\dot{u}_{g}=P_{*}\left(\tilde{u}-u_{g}\right)^{2} / d
$$

となる。ここに,

$$
P_{*}=(1 / 2) \cdot\left(A_{2} / A_{3}\right) \cdot C_{D} /
$$

$$
\left[\left\{1+4 k_{3}\left(k^{2} / d^{2}\right)\right\}\left(\sigma / \rho+C_{M}\right)\right]
$$

である。

式 (44) を積分し, 初期条件 $t=0$ で $u_{g}=0$ を考慮す ると，

$$
\frac{u_{g}}{u_{*}}=\frac{P_{*} \bar{A}_{*}^{2}\left(u_{*} t / d\right)}{1+P_{*} \bar{A}_{*}\left(u_{*} t / d\right)}
$$

ただし，

$$
\bar{A}_{*}=\tilde{u} / u_{*}
$$

となる。

$u_{g}=d x / d t$ であるから, 式 (46) をさらに積分して 初期条件 $t=0$ で $x=0$ を考慮すると結局,

$$
x / d=\left\{K t_{*}-\ln \left|K t_{*}+1\right|\right\} / P_{*}
$$

となる。ここに，

$$
\begin{aligned}
& K=P_{*} \bar{A}_{*} \\
& t_{*}=u_{*} t / d
\end{aligned}
$$

である。なお, 計算の都合上式 (48) を次式で近似する。

$$
K t_{*}=(3 / 2) \sqrt{P_{*} x / d}
$$

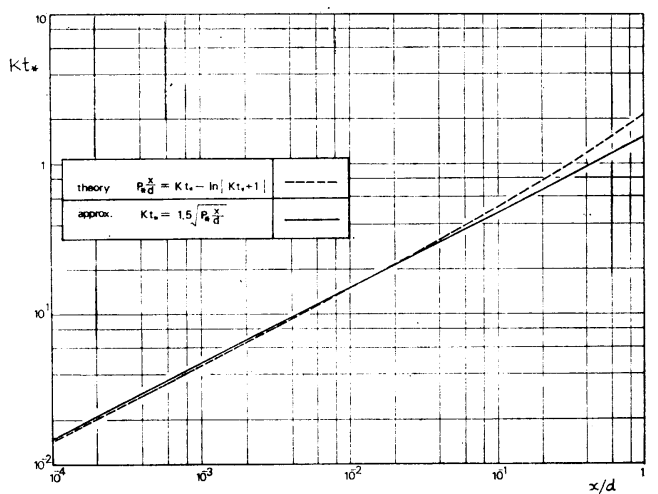

図-12 式 (48) と式 (51) との比較

この式による近似程度は 図一12 に示すように $K t_{*}$ の 大きくない範囲で十分良好であり，後述する突起間距離 に対しては十分な精度が期待される。

式 (46) および (51) より $t_{*}$ を消去すると,

$$
u_{g} / u_{*}=\bar{A}_{*} \cdot 3 \sqrt{P_{* \zeta}} /\left(2+3 \sqrt{P_{* \zeta}}\right)
$$

ただし、

$$
\zeta=x / d
$$

となり, 転動距離と転動速度の関係が得られる。

c) 突起の乗越確率

球の突起乗越確率は $\omega_{1}$ が $\omega_{c}$ をこえる確率として与 えられる。式 (52) および（42）から得られる (38) で与えられる $\omega_{c}$ と等值し，これを $\zeta$ にいて解 きその根を $\zeta_{c}$ とすると，

$$
\zeta_{c}=\frac{8\left\{1+4\left(k^{2} / d^{2}\right)\right\} \Delta_{*}}{9 P_{*}\left[T \left\{1+\frac{\left.4\left(k^{2} / d^{2}\right)-2 \Delta_{*}\right\} \cdot}{\left.-\sqrt{1+4\left(k^{2} / d^{2}\right)} \sqrt{2 \Delta_{*}}\right]^{2}}\right.\right.}
$$


となる。ただし，

$$
T=k_{3} \bar{A}_{*} u_{*} / \sqrt{g d}
$$

である。

ところで, 粗面の状態は突起強度 $\Delta_{*}$, 無次元突起間 隔 こでは $\Delta_{*}=\Delta_{*_{0}}$ で $\zeta$ が平均值 $\zeta_{0}$ の指数分布に従うと した河床面モデルを考えることにする。すなわち，らの 確率密度関数 $((\zeta)$ は次式で与えられる。

$$
\psi(\zeta)=\left(1 / \zeta_{0}\right) \cdot \exp \left(-\zeta / \zeta_{0}\right)
$$

このとき, 球の突起乗越確率 $p_{r}$ は,

$$
p_{r 0}=\int_{\zeta_{c}}^{\infty} \psi(\zeta) d \zeta=\zeta_{0} \cdot \psi\left(\zeta_{c}\right)
$$

で計算される。

d) 固定床での step length

砂れきが突起の存在する粗面を転動し, 突起に衝突後 あるものは停止し, 残りは再び次の突起に向かって転動 を開始するものと考える。このとき，砂れきが動き始め てから $m$ 個目の突起で停止する確率 $p_{s t m}$, およびそ のときの砂れきの無次元移動距離 $\zeta_{m}$ はそれぞれ，

$$
p_{\text {stm }}=p_{r 0}{ }^{m-1}\left(1-p_{r 0}\right)
$$

$\zeta_{m} \doteqdot m \zeta_{0}$

で与えられる。したがって，砂れきが移動開始してから 停止するまでの無次元移動距離の平均值, すなわち無次 元平均 step length $\lambda$. は次式で与えられる。

$$
\lambda=\lim _{n \rightarrow \infty} \sum_{j=1}^{n} p_{r 0}^{j-1}\left(1-p_{r 0}\right) j \zeta_{0}
$$

この式の右辺の無限級数は収束して結局,

$$
\lambda=\zeta_{0} /\left(1-p_{r 0}\right)
$$

となる。式 (60) は, Einstein ${ }^{2), 3)}$ が流体力による非停 止確率について展開した考え方にならったもので，ここ でもその効果を考虑して，

$$
\lambda=\zeta_{0} /\left\{\left(1-p_{r_{0}}\right) \cdot\left(1-p_{0}\right)\right\}
$$

とする。なお $p_{0}$ は式 (21) で与えられる流体力が転動 限界をこえる確率で代用できるものとする。

\section{e) 実験的検討}

式 (54),(57) および（61）を検証するため実験を行 った。実験は初期移動の実験に用いた水路にまず所定の ガラスビーズを 1 層に敷きニス付けし, 着色ビーズをト レーサーとして移動距離の分布を測定した。得られたデ ータは粒径で無次元化した後, 超過確率として整理し, 便宜的に step length の分布を指数型に仮定して平均 無次元 step length $\lambda$ を求めた。すなわち $f_{X}(\xi)$ を無 次元 step length の確率密度関数とすると,

$$
f_{X}(\xi)=(1 / \lambda) \exp (-\xi / \lambda)
$$

であり，超過確率 $G(\xi)$ は，

$$
G(\xi)=\int_{\xi}^{\infty} f_{X}(\xi) d \xi=\exp (-\xi / \lambda)
$$

となる。
また同様の実験を自然砂 $(d=0.193 \mathrm{~cm}, \sigma / \rho=2.65)$ についても行った。これらの実験で得られた超過確率 $G(\xi)$ の例を 図一13 および 14 に示した。これによる と, 平坦粗面上での step length はほぼ指数型である

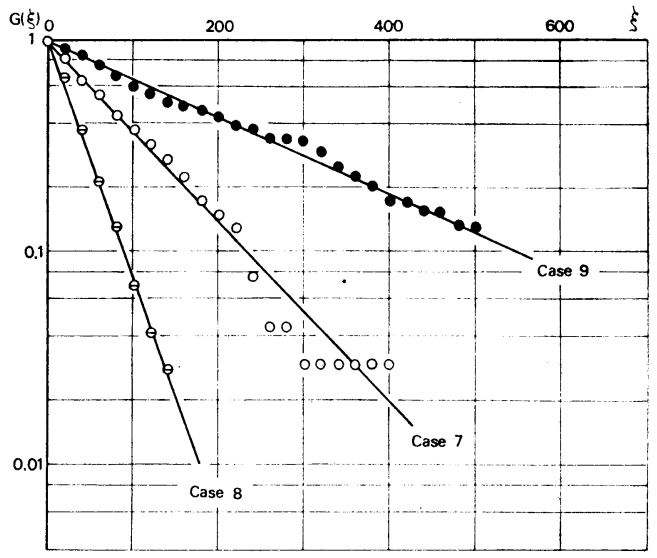

図一13 固定床での step length の超過確率 の例（ガラスビーズ）

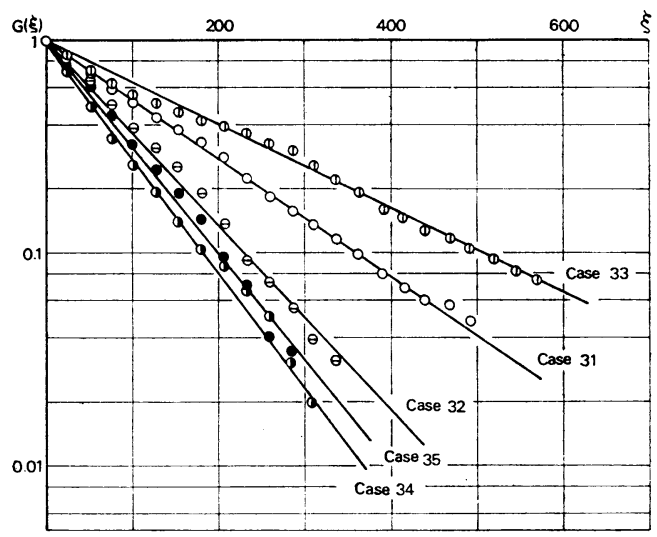

図-14 固定床での step length の超過 確率の例 (砂)

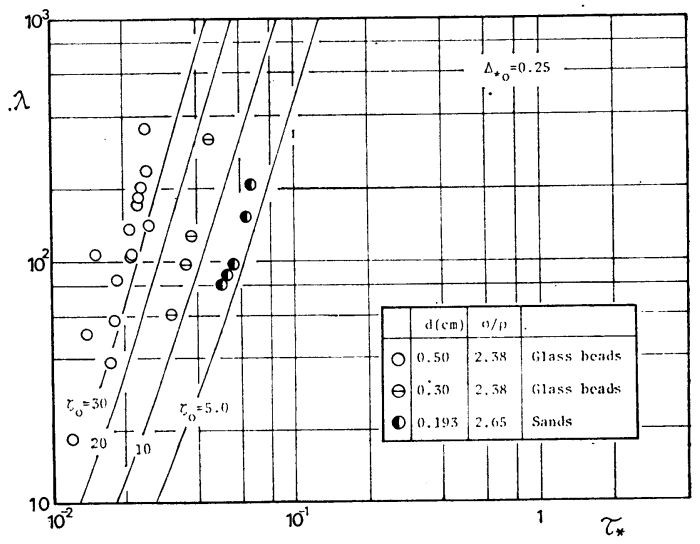

図一15 固定粗面上での step length 
といえ,この傾きから無次元平均 step length $\lambda$ が求め られる。このようにして得られた $\lambda$ の無次元せん断応 力 $\tau_{*}$ に対する変化を 図一15 示した。

なお，図一15には， $\Delta_{*_{0}}=0.25, \zeta_{0}=5,10,20,30$ の 場合について式 (54), (57) および (61) で与えられる理 論曲線を計算して併示してある。この計算においては, $A_{2}=\pi / 4, A_{3}=\pi / 6, C_{M}=0.5, k_{3}=1.0, k^{2}=(1 / 10) d^{2}$, $\sigma / \rho=2.65, C_{D}=0.4$ とし, また流速分布に対数則を仮 定し $z=0.7 d$ の高さの 局所流速を用い $\bar{A}_{*}=7.62$ と した。この計算曲線を実験值と比較すると実験での粗面 状態,したがって床面構成材料によってら。を適当に選 べば，良く合致することがわかる。

今回の実験ではほぼ完全に均一球の $d=0.5 \mathrm{~cm}$ のガ ラスビーズでは床面の均一度が高く $\zeta_{0} \approx 30$, 若干形状に むらがあり床面の均一度が少し失われた $d=0.3 \mathrm{~cm}$ の ガラスビーズでは $\zeta_{0} \approx 10$ となっている。さらに形状, 粒径ともガラスビーズに比べ広い分布を持っている自然 砂では粗面均一度は低く $\zeta_{0} \approx 5$ である。これらの実験 結果より，実際の砂面では扮扮む䄈一様といえる状態で ら。は 5 10 程度と予想される。

なお， $\Delta_{* 0}$ の選び方は $\Delta_{b}$ が転動面からの高さであり， 転動面をどこにとるかが難しく䁔味ともいえるが, Che$\mathrm{pil}^{18)}$ の packing coefficient, 間隔 $3 d$ の六角形パター ン配置モデルとほぼ一致しており, 実際の砂面状態に近 いものと考えられる。

\section{（2）移動床での step length}

a) 移動床での step length のモデル

前節では固定床での砂れきの流送機構を, 転動, 衝乲 の力学モデルを介在させて説明を試みた。しかし移動床 では，たとえば step length に関する実験データを見 てもわかるように固定床とは異なった機構に基づいてい ることが予想される。特に突起への衝突機構がまったく 異なる。すなわち, 固定床では転動してきた砂れきの運 動量保存を考えたが, 移動床では突起を形成している砂 粒およびそれに隣接した数個の砂粒がずれ動く場合があ り,そのため転動してきた砂粒のもつ運動量が減少し停 止しやすくなる。しかし衝突の際, 突起砂粒およびその 隣接砂粒が何個, どの方向へ, どの程度移動するか, す なわちもともと転動してきた砂粒の運動量がどれくらい 減少するのかが判然としない。

そこで,ここでは砂れきの挙動をとくに step length としてとらえその特性を表現することが主目的であるこ とから，簡単に次のようなモデルによって取り扱う。 loose な境界での衝突の機構を詳細に記述することおよ びその厳密な実験的検証が必要なのはいらまでもないが これは今後の課題とする。
さて転動してきた砂粒が突起に衝突した際，突起およ び隣接砂粒を含めて $n$ 個の砂粒が動けば転動してきた砂 粒自身の持っている運動量が運動を停止せざるを得ない までに減じるもの上し，またこのときずれ動く砂粒は， 流体力による可動状態にあるものと仮定する。

なお, このモデルの適用範囲は固定床上の衝突では平 均的に突起乗越条件をみたすもの，すなわち 図一15の 理論曲線の右下の領域である。このような突起の平均間 隔を $\zeta_{0}^{\prime} d$ とし, また 1 つの砂粒が可動状態にある確率 が $p_{0}$ で各砂粒について独立であるとすると, 結局転動 砂れきが停止する突起の平均間隔は $\zeta_{0}{ }^{\prime} d / p_{0}{ }^{n}$ 之なり, 無次元の平均 step length は, 転動砂れきの流体力に よる非停止確率を考慮して次式で与えられる。

$$
\begin{aligned}
& \lambda=\zeta_{0}^{\prime} /\left\{p_{0}{ }^{n}\left(1-p_{0}\right)\right\} \\
& \text { ここに, } n, \zeta \zeta^{\prime} \text { は }
\end{aligned}
$$

本来ならば力学機構 の面から議論される べき量であるが,こ こでは実験定数とす る。

図一16には，1! $\left\{p_{0}{ }^{n}\left(1-p_{0}\right)\right\}$ の $\tau_{*}$ に対する変化を示し たがこれによる之 2は $\tau_{*}$ に対し極小 值を有し, 極小値に 対応する $\tau_{*}$ は $n$ に よって決定される。

\section{b) 実験的検討}

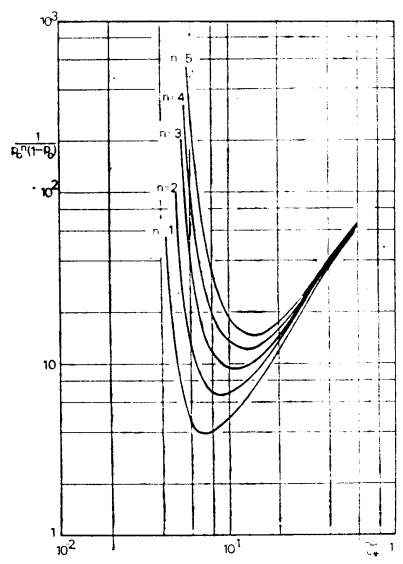

図-16 $1 / p_{0}{ }^{n}\left(1-p_{0}\right) \sim \tau_{*}$

固定床実験を行ったのと同じ水路に，所定の砂を厚さ $7 \mathrm{~cm}$ に敷き, 着色砂をトレーサーとして step length を測定した。実験に用いた砂は $d=0.14 \mathrm{~cm}, \sigma / \rho=2.62$ および $d=0.102 \mathrm{~cm}, \sigma / \rho=2.61$ の 2 種類である。

step length のデータは各ケースにつき 100 150 個 を収録し, 超過確率として整理, 指数型分布を仮定して 平均 step length $\lambda d$ を求めた。図一17 は移動床での step length の超過確率の例で, ほぼ指数型に適合して いる。なお，実験は顕著な河床波の形成されないほぼ平 坦河床で行った。

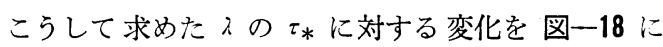
示した。図一18には篠原・椿 ${ }^{14)}$, 高橋 ${ }^{15)}$ および矢野・ 土屋・道上 ${ }^{6)}$ のデータも併示し,また $\Delta_{* 0}=0.25 ; \zeta_{0}=5$, 10 亿対する 2 本の固定床での理論曲線, $\zeta_{0}{ }^{\prime}=10 ; n=2$, 3,4 に対する 3 本の移動床のモデルの計算曲線をも示し た。

これより無次元せん断応力の増加とともに，固定床で は step length が増加するが, 移動限界をこえると, 


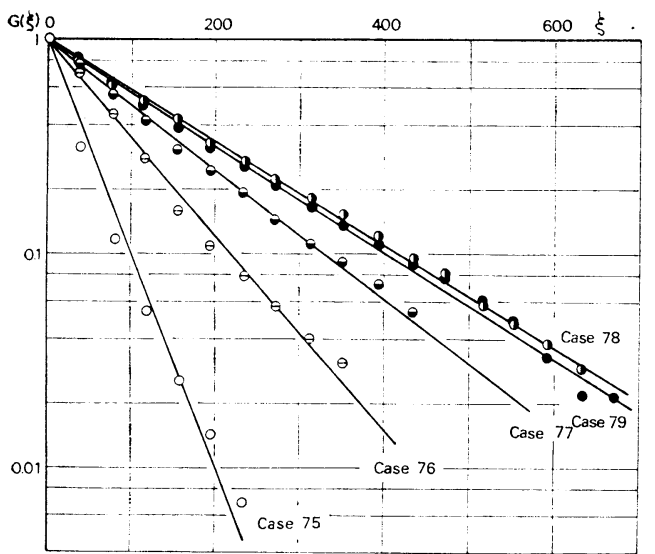

図-17移動床での step length の 超過確率の例

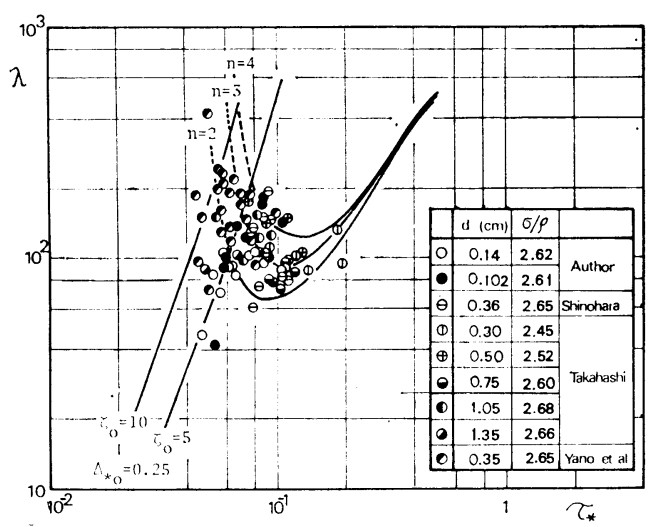

図一18 移動床での step length

移動砂粒の運動量が突起およびその周辺の砂粒に奪われ てしまうことから step length が減少し，さらに $\tau_{*}$ が大 きくなると流体力の効果が運動量減少効果を上まわり, 再び step length が増加するという特性が示され, 実 験的にも検証された。なお, 河床の整形のしかたが, 特 に $\tau_{*}$ の小さいとき(いわゆる限界掃流力付近)，きわ めて大きな影響を step length におよぼし, 従来の実 験值においてばらつきが大きいことの原因となっている といらことができる。

\section{4. 結論}

本研究は，さまざまな移動床現象を砂れきの運動機構 に基づいて統一的に，しかも合理的に説明するための基 礎として, 水流による砂れきの移動特性の代表量である pickup rate および step length について力学モデル を介在させてその推定について考察し実験的に検討した ものである。
まず pickup rate については, 初期移動を運動方程 式に基づいて離脱過程として扱い実験的に検討した。す なわち転動離脱モデルを考え, 剛体球に対する運動方程 式, 正規分布に従う流体力の変動, 初期移動に支配的な 乱れの周期に基づく流体力の作用持続時間の概念を用い て, 砂れきの離脱に要する時間の逆数として pickup rate を求め, 従来の実験值 および今回行った実験を通 してその適合性を検証した。その結果, ここに展開した モデルで, 広、条件に対して初期移動の特性が記述でき ることが示された。

また, step length については, 砂れきの停止機構を 床面の突起との衝突によるものとし, まず衝突前後に運 動量保存則, また衝突後の突起乗越条件にエネルギー保 存則を適用した。一方, 砂れきの流送過程を転動機構で 包括的に扱えるものとし, 転動に対する運動方程式をも とに転動距離と転動速度の関係を求め, 突起乗越のため の転動距離の限界值を得た。さらに, 粗面構成を突起強 度と突起間隔の確率モデルで扱い, 突起乗越確率を求 め, 流体力の効果を含めて step length の平均值を推 定し, 実験によって検討した。その結果, 床面の均一性 の step length への大きな影響がある程度定量的に示 された。

なお, 移動床についてはこのモデルのままでは突起に 衝突の際の運動量の河床砂粒への伝達が説明できず, こ こでは突起を含め $n$ 個の砂粒のずれ動きで転動の運動量 を失ない停止するものと仮定してモデル化し, 移動床で の step length の特性の表現を試みた。従来の実験デ ータおよび著者らの実験値によって検討した結果, こう したモデルで移動床の step length の特性が十分表わ されることがわかった。

なお，こうした loose な境界での砂粒の相互干涉的 な力学機構, 河床近傍の流れ特性, 流体力とその変動の 評価など, 残されたしかも本質的な問題は多く, 今後詳 細な実験と検討が必要であり著者らもこうした問題に取 り組むつもりであるが, 本研究では, 砂移動の基本量で ありまた stochastic model のパラメーターとしての pickup rate と step lengthを, 一面であるかもしれな いがその力学機構を踏まえて推定する方法を示した。今 後, これらの量を用いて実際の流砂現象に伴ら河床変形 の記述，予測などへの適用性についても，先に述べた基 礎研究と併行して進めたいと考える。

\section{参考 文 献}

1) Einstein H.A. : Der Geschiebetrieb als Wahrscheinlichkeitsproblem, Verlag Rascher, Zurich, 1937.

2) Einstein H.A. : Formulas for the Transportation of Bed Load, Trans. ASCE, Paper No. 2140, pp. 561597, 1942.

3) Einstein H.A. : The Bed Load Function for Sedi- 
ment Transportation in Open Channel Flows, Technical Bulletin, No. 1026, U.S. Department of Agriculture, Soil Conservation Service, p. 78, 1950.

4) Paintal A.S. : Stochastic Model of Bed Load Transport, Journal of Hydraulic Research, IAHR, 9, No. 4, pp. 527-554, 1971.

5) Hubbell D.W. and W.W. Sayre : Sand Transport Studies with Radioactive Tracers, Proc. ASCE, HY 3, pp. 39-68, 1964.

6）矢野勝正・土屋義人・道上正䂓：砂れきの流送機柈の確 率過程としての特性について, 京大防災研究所年報第 11 号 B, pp. 61-73, 1968.

7) Chen Charng-Ning and M.R. Carstens : Mechanic of Removal of a Spherical Particle from a Flat Bed, Proc. 15th Congr. IAHR, Turkey, Vol. 1, pp. 225233, 1973.

8) Einstein H.A. and E.A. El-Samni : Hydrodynamic Forces on a Rough Wall, Review of Modern Physics, 21, pp. 520-524, 1949.

9) Chepil W.S. : The Use of Evenly Spaced Hemispheres to Evaluate Aerodynamic Forces on a Soil Surface, Trans. A.G.U., Vol. 39, No. 3, pp. 397404, 1958.

10) White C.M. : The Equilibrium of Grains on the
Bed of a Stream, Proc. Royal Society of London, Vol. 174 A, pp. 322-334, 1940.

11) Kalinske A.A. : Movement of Sediment as Bed Load in Rivers, Trans. A.G.U., Vol. 28, No. 4, pp. 615-620, 1947.

12) Grass A.J. : Initial Instability of Fine Bed Sand, Proc. ASCE, HY 3, pp. 619-632, 1970.

13) Cheng E.D.H. : Incipient Motion of Large Roughness Elements in Turbulent Open Channel Flow, Ph.D. thesis, Utah State University, 1969.

14）篠原䔆爾・椿東一郎：河床砂碟の移動機構に関する一考 察, 九大応用力学研究所報, 第 10 号, pp. 85-94, 1957.

15）高橋正佑 : 河床破碩の流送に関する実験的研究第一報, 新砂防, 第 18 巻第 4 号, pp. 5-14, 1966.

16）鈴木幸一・辻本哲郎：砂れきの移動確率に閣する考察, 昭和 48 年度土木学会関西支部年次学術講演会講演概要, II $-34,1973$.

17) Christensen B.A. and T.Y. Chiu : Water and Air Transport of Cohesionless Materials, Proc. 15th Congr. IAHR, Turkey, Vol. 1, pp. 245-252, 1973.

18) Chepil W.S. : Equilibrium of Soil Grains at Threshold of Movement by Wind, Soil Science Society Proceedings, 23(6), pp. 422-428, 1959.

(1975.4.19. 受付) 